\title{
Comment on: “Differences in In Vitro Properties of Pancreatin Preparations for Pancreatic Exocrine Insufficiency as Marketed in Russia and CIS"
}

\author{
Karl-Uwe Petersen ${ }^{1}$ (D)
}

Accepted: 20 September 2021 / Published online: 20 October 2021

(c) The Author(s) 2021

Referring to the publication by Maev et al. [1], it can be agreed with the authors that particle size, label claim-compliant lipase activity, high batch-to-batch conformity, gastric resistance and quick enzyme release in the intestine are relevant parameters for successful treatment of pancreatic exocrine insufficiency with pancreatic enzyme-replacement therapy (PERT). However, the authors' claim that the particle size of PERT should be smaller than $2 \mathrm{~mm}$ appears debatable, and it should be emphasized that particle size distribution (PSD) is also relevant.

After measuring particle sizes, the authors concluded that only Kreon and not other PERTs available in Russia or CIS (Commonwealth of Independent States: Armenia, Azerbaijan, Belarus, Kazakhstan, Kyrgyzstan, Moldova, Russia, Tajikistan, Uzbekistan) fulfilled the criterion of a suitable particle size of $2 \mathrm{~mm}$. Ermytal, Pangrol and Panzytrat displayed a significantly larger particle size than Kreon when using the selected parameter Feret $\max \mathrm{X}_{50}$. Unfortunately, the authors provided no data regarding the PSD or $\mathrm{X}_{10}$ and $\mathrm{X}_{90}$. For Ermytal, Pangrol and Panzytrat, the PSD was small because of the production process (sieved microtablets). This is not necessarily true for pellet-based products such as Kreon. Thus, evidence is lacking that the average diameter is not caused by the combination of two particle fractions with diameters either too big or too small to empty simultaneously with the meal. For a complete evaluation, data regarding the length/width ratio of the cylinder-shaped pellets would also be needed (Feret $\min \mathrm{X}_{50}$ data missing). The authors pointed out that the critical dimension of the

This comment refers to the article available online at https://doi. org/10.1007/s40268-020-00326-z.

Karl-Uwe Petersen

KarlUwe.Petersen@post.rwth-aachen.de

1 Medical Faculty, RWTH Aachen University, Aachen, Germany particle is the length of the cylinder, but it has been shown that particles of that shape can leave the pylorus lengthwise [2]. Given that, for Kreon, the Feret max is already quite small, it is possible that quite a high number of particles have a width small enough to leave the pylorus before the chyme, especially as even $2 \mathrm{~mm}$ enteric-coated pancreatin microspheres have been shown to do so [3].

Even if all Kreon particles showed a very narrow PSD and a rather round shape, it is questionable whether the particle size difference of $1 \mathrm{~mm}$ compared with Ermytal, Pangrol and Panzytrat in any way affects the efficiency of the PERT. It is true that the European guideline [4] recommends particles smaller than $2 \mathrm{~mm}$, but it has only recently been demonstrated that there is no scientifically sound evidence for this cut-off value, which needs serious re-evaluation [5].

This criticism includes the fact that the cited guideline has failed to provide clinical evidence for the claimed advantage of smaller-sized particles. Instead, that document cited a study that, rather than reporting a trial comparing different pellet sizes for gastric emptying and efficacy, provided evidence for $2 \mathrm{~mm}$ particles emptying faster (not slower) than a pancake meal from the stomach of patients with chronic pancreatitis [3].

Finally, Maev et al. [1] themselves conceded that there was no evidence to suggest an impact on clinical outcome of particle size differences in the discussed range. So, we agree with the author that studies with direct comparisons are lacking.

Acknowledgements The author thanks Dr. A. Müller-Lucks for revision of the manuscript.

\section{Declarations}

Funding The author has not received funding for the preparation of this manuscript. 
Conflict of interest In the past 2 years, KUP has received consulting fees from Behring, BioQPharma, Hexal, Luvos, Nordmark, PAION, Ursapharm, and VarmX.

Open Access This article is licensed under a Creative Commons Attribution-NonCommercial 4.0 International License, which permits any non-commercial use, sharing, adaptation, distribution and reproduction in any medium or format, as long as you give appropriate credit to the original author(s) and the source, provide a link to the Creative Commons licence, and indicate if changes were made. The images or other third party material in this article are included in the article's Creative Commons licence, unless indicated otherwise in a credit line to the material. If material is not included in the article's Creative Commons licence and your intended use is not permitted by statutory regulation or exceeds the permitted use, you will need to obtain permission directly from the copyright holder. To view a copy of this licence, visit http://creativecommons.org/licenses/by-nc/4.0/.

\section{References}

1. Maev IV, Kucheryavyy YA, Gubergrits NB, Bonnacker I, Shelest EA, Janssen-van Solingen GP, Domínguez-Muñoz JE. Differences in in vitro properties of pancreatin preparations for pancreatic exocrine insufficiency as marketed in Russia and CIS. Drugs R D. 2020;20:369-76. https://doi.org/10.1007/s40268-020-00326-z.

2. Loreno M, Bucceri AM, Catalano F, Blasi A, Brogna A. Gastric clearance of radiopaque markers in the evaluation of gastric emptying rate. Scand J Gastroenterol. 2004;39:1215-8. https://doi.org/ 10.1080/00365520410003560.

3. Bruno MJ, Borm JJ, Hoek FJ, Delzenne B, Hofmann AF, de Goeij $\mathrm{JJ}$, et al. Gastric transit and pharmacodynamics of a two-millimeter enteric-coated pancreatin microsphere preparation in patients with chronic pancreatitis. Dig Dis Sci. 1998;43:203-13. https:// doi.org/10.1023/a:1018813229334.

4. Löhr JM, Domínguez-Muñoz JE, Rosendahl J, Besselink M, Mayerle J, Lerch MM, et al. United European Gastroenterology evidence-based guidelines for the diagnosis and therapy of chronic pancreatitis (HaPanEU). United Eur Gastroenterol J. 2017;5:15399. https://doi.org/10.1177/2050640616684695.

5. Petersen K-U, Malfertheiner P, Mössner J. The role of sphere size in the context of pancreatin therapy for exocrine pancreatic insufficiency: a systematic review. J Gastrointestin Liver Dis. 2021. https://doi.org/10.15403/jgld-2985. 